J. Clin. Chem. Clin. Biochem.

Vol. 19, 1981, pp. 17-20

\title{
Evidence of Age-Dependent Activity Increase of Poly(C)-Avid Serum Ribonuclease in Man
}

\author{
By M. Francesconi, S. Meryn, K. Moser
}

Erste Medizinische Universitätsklinik (Vorstand Prof. Dr. Dr. h. c. E. Deutsch), Wien and

K. Bauer

Institut für klinische Chemie und Laboratoriumsdiagnostik (Vorstand Prof. Dr. F. Gabl), Universität Wien

(Received February 19/June 19, 1980)

\section{Herrn Professor Dr. Franz Gabl zum 60. Geburtstag gewidmet}

Summary: The activity of ribonuclease (EC 3.1.4.22) was estimated in sera of 401 normal subjects (normal renal function, no signs of catabolism), age ranging from 16 to 100 years (mean: $50.25 \pm 19.98$ ) with Poly (C) as substrate. Further activity was measured with the substrates Poly $(U)$, Poly $(A)$ and Poly $(G)$ in 10 sera from each age decade between 21-30 years and 81-90 years. Greatest activity was found with Poly (C) as substrate (mean: $15.88 \mathrm{kU} / 1$ \pm 9.57 ). Covariant analysis (age as covariant) revealed no sex-related activity distribution at any age, whereas the age-dependent activity increase was highly significant $(\mathrm{p}<0.001 ; 11-20$ years: $9.48 \mathrm{kU} / 1 \pm 3.07 ; 81-90$ years: $34.72 \mathrm{kU} / 1 \pm 5.88)$. Activity with the other substrates was very low and constant throughout all ages. It seems to be mandatory to consider the age of the patient when interpreting ribonuclease activity.

\section{Nachweis der altersabhängigen Aktivitätszunahme der Poly(C)-aviden Ribonuclease im Serum beim Menschen}

Zusammenfassung: Die Aktivität der Ribonuclease (EC 3.1.4.22) wurde im Serum von 401 Normalpersonen (normale Nierenfunktion, kein Katabolismus), Alter 16-100 Jahre (Mittel 50,25 $\pm 19,98$ ) mit Poly (C) als Substrat gemessen. Weiters wurde die Aktivität mit den Substraten Poly (U), Poly (A) und Poly (G) in jeweils 10 Sera der Altersdekaden 21-30 bị 81-90 Jahren gemessen. Die größte Aktivität wurde mit Poly (C) als Substrat gefunden (Mittel 15,88 kU/1 $\pm 9,57$ ). Mittels Kovarianzanalyse (Alter als Kovariante) zeigte sich keine geschlechtsgebundene Aktivitätsverteilung, während eine hochsignifikante altersbedingte Aktivitätszunahme nachgewiesen werden konnte (p < 0,001; 11-20 Jahre: 9,48 kU/1 $\pm 3,07 ; 81-90$ Jahre: 34,72 kU/1 $\pm 5,88$ ). Die Aktivität mit den drei anderen Substraten war sehr niedrig und konstant über alle Altersgruppen. Es erscheint erforderlich zu sein, das Alter der Patienten bei der Beurteilung der Ribonucleaseaktivität zu berücksichtigen.

\section{Introduction}

Since the discovery of ribonuclease activity in human serum, efforts have been made to characterize this enzyme (ribonuclease I; ribonucleate $3^{\prime}$-pyrimidinooligonucleotide hydrolase; EC 3.1.4.22) with regard to activity and clinical relevance in different disease conditions $(1,2,3)$. There is evidence of elevated ribonuclease activity due to impaired renal function $(2,4,5)$, during pregnancy (6) and in catabolic conditions (7). Some authors pointed out that the enzyme may be of value as a cancer diagnostic $(8,9,10)$. In recent publications this latter suggestion has been looked at more critically $(11,12)$. It was the aim of this investigation to elucidate the influence of sex and age on ribonuclease activity, a - question of great importance in view of the age distribution of tumor patients. Furthermore it was investigated whether preferential cleavage of homopolyribocytidylates is common on sera of both sexes and all age groups.

\section{Materials and Methods}

Probands and samples

Enzyme activity was assayed in sera of 401 volunteers of both sexes in good health, age ranging from 16 to 100 years.

The following criteria had to be fulfilled:

(A) normal renal function: Blood urea nitrogen ${ }^{1}$ ) $<7.2 \mathrm{mmol} / 1$; Creatinine $^{1}$ ) $<100 \mu \mathrm{mol} / \mathrm{l}$; Creatinine-clearance $>100 \mathrm{ml} / \mathrm{min}$ (13).

(B) no signs of catabolic condition: weight loss $<2 \mathrm{~kg}$ within 4 weeks before blood sampling.

1) SMA-60/6 Technicon Corp. 


\section{Ribonuclease assay}

Enzyme was assayed by a modified Zimmerman method (14). Ten $\mathrm{ml}$ of fasting venous blood was allowed to clot for 1 hour at room temperature and was then centrifuged at $750 \mathrm{~g}$ for 15 minutes. Ribonuclease estimation was performed either immediately thereafter, or the serum was stored frozen at $-20^{\circ} \mathrm{C}$ and enzyme was assayed at a later time.

Reaction mixture consisted of $100 \mu \mathrm{g}$ Poly $\left.(C)^{2}\right), 0.15 \mathrm{ml}$ of buffer containing $0.1 \mathrm{~mol} / 1 \mathrm{KH}_{2} \mathrm{PO}_{4}$ and $0.05 \mathrm{~mol} / 1 \mathrm{Na}_{2} \mathrm{~B}_{4} \mathrm{O}_{7}$ $10 \mathrm{H}_{2} \mathrm{O}$ with $\mathrm{pH} 6.5 ; 50 \mu \mathrm{l}$ of serum diluted $1: 200$ with saline.

After an incubation period of 15 minutes at $37^{\circ} \mathrm{C}$ samples were transferred to an ice bath and the reaction was stopped with $0.25 \mathrm{ml}$ of ice-cold $1.2 \mathrm{~mol} / 1$ perchloric acid containing $0.02 \mathrm{~mol} / 1$ lanthanum nitrate. After 20 minutes of ice bath the precipitate was removed by centrifugation at $12000 \mathrm{~g}$ for 30 minutes at $4{ }^{\circ} \mathrm{C}$. The supernatant was diluted with $\mathrm{H}_{2} \mathrm{O}$, absorbance was measured at $278 \mathrm{~nm}$ (Zeiss, PMQ 3). Enzyme and substrate blanks were run side by side. The same procedure was employed with the substrates Poly $\left.(U)^{2}\right)$, Poly $\left.(A)^{2}\right)$ and Poly $(G)^{2}$ ).

\section{Activity definition}

One ribinuclease unit is defined as the activity that renders $1 \mu \mathrm{mol}$ of Poly (C) acid soluble in one minute at $\mathrm{pH} 6.5$ and $37^{\circ} \mathrm{C}$. Analogously activities are defined for the cleavage of Poly (U), Poly (A) and Poly (G). The absorbance and the molar absorption coefficient were estimated with reference to the monomeres CMP, UMP, AMP and GMP in accordance with the Pabst-tables ${ }^{3}$ ). Obviously not all acid soluble material in the supernatant consists of mononucleotides, but the differences in absorption coefficients of mono- and oligomeres were negligible in this case.

\section{Evaluation}

Activities were evaluated separately for the two sexes and additionally for age, with ages grouped as decades: youngest decade 11-20 years, oldest decade $91-100$ years. By means of covariant analysis (age as covariant) it was investigated whether there was an age and/or sex-dependent activity distribution (15). The activities with Poly (U), Poly (A) and Poly (G) as substrates were compared with the activities obtained using Poly $(C)$ within each decade $(n=10)$.

\section{Results}

In order to show the uniform distribution of ribonuclease activity between both sexes within each decade of age, mean values, standard deviation and the median was calculated for male and female subjects separately, results are given in table 1 . Due to the low number of samples investigated no median could be calculated for males of 11-20 and 91-100 years, or for females of 91-100 years.

In adults between 21 and 90 years covariant analysis revealed no sex-linked differences in enzyme activity, whereas the age-dependent activity increase was highly significant $(F=38.25 ; \mathrm{p}<0.001)$. In figure 1 ribonuclease activity of all sera (abscissa) is plotted against the age of the subject (ordinate). According to the results of covariant analysis there was a significant correlation between age and enzyme activity $(r=0.683 ; p<0.001)$.

2) Miles Research products, Miles Laboratories, Inc. Elkhart, Indiana 46514 , USA.

3) P. L. Biochemicals Milwaukee, Wisconsin 53205 Eighth Printing, 1976.
Tab. 1. Distribution of Poly (C)-avid ribonuclease activity in age decades from 11-20 to $91-100$ years.

\begin{tabular}{|c|c|c|c|c|}
\hline \multirow[t]{2}{*}{$\begin{array}{l}\text { Age } \\
\text { (a) }\end{array}$} & \multirow[t]{2}{*}{ Sex } & \multirow[t]{2}{*}{$\mathrm{n}$} & \multicolumn{2}{|c|}{$\begin{array}{l}\text { Poly(C)-avid ribonuclease } \\
(\mathrm{kU} / \mathrm{l})\end{array}$} \\
\hline & & & $\bar{x} \pm s$ & Median \\
\hline $11-20$ & $\begin{array}{l}0 \\
8\end{array}$ & $\begin{array}{r}4 \\
11\end{array}$ & $\begin{array}{r}8.36 \pm 2.89 \\
10.61 \pm 3.26\end{array}$ & $\overline{10.6}$ \\
\hline $21-30$ & $\begin{array}{l}0 \\
q\end{array}$ & $\begin{array}{l}29 \\
35\end{array}$ & $\begin{array}{r}9.65 \pm 3.11 \\
10.46 \pm 3.23\end{array}$ & $\begin{array}{l}8.5 \\
9.24\end{array}$ \\
\hline $31-40$ & $\begin{array}{l}0 \\
q\end{array}$ & $\begin{array}{l}19 \\
47\end{array}$ & $\begin{array}{l}11.40 \pm 3.38 \\
11.70 \pm 3.34\end{array}$ & $\begin{array}{l}11.4 \\
10.7\end{array}$ \\
\hline $41-50$ & $\begin{array}{l}0 \\
8\end{array}$ & $\begin{array}{l}18 \\
31\end{array}$ & $\begin{array}{l}12.61 \pm 3.55 \\
13.21 \pm 3.63\end{array}$ & $\begin{array}{l}12.4 \\
13.00\end{array}$ \\
\hline $51-60$ & $\begin{array}{l}0 \\
q\end{array}$ & $\begin{array}{l}27 \\
41\end{array}$ & $\begin{array}{l}14.39 \pm 3.79 \\
14.74 \pm 3.84\end{array}$ & $\begin{array}{l}13.10 \\
13.01\end{array}$ \\
\hline $61-70$ & o & $\begin{array}{l}17 \\
49\end{array}$ & $\begin{array}{l}19.63 \pm 4.43 \\
16.41 \pm 4.01\end{array}$ & $\begin{array}{l}16.20 \\
14.70\end{array}$ \\
\hline $71-80$ & $\begin{array}{l}\delta \\
q\end{array}$ & $\begin{array}{l}12 \\
29\end{array}$ & $\begin{array}{l}24.43 \pm 4.90 \\
24.13 \pm 4.91\end{array}$ & $\begin{array}{l}20.60 \\
20.90\end{array}$ \\
\hline $81-90$ & $\stackrel{0}{\phi}$ & $\begin{array}{r}8 \\
15\end{array}$ & $\begin{array}{l}30.94 \pm 5.56 \\
38.50 \pm 6.20\end{array}$ & $\begin{array}{l}28.30 \\
38.30\end{array}$ \\
\hline $91-100$ & $\begin{array}{l}0 \\
\$\end{array}$ & $\begin{array}{l}1 \\
4\end{array}$ & $\begin{array}{l}42.18 \\
41.15 \pm 6.41\end{array}$ & - \\
\hline
\end{tabular}

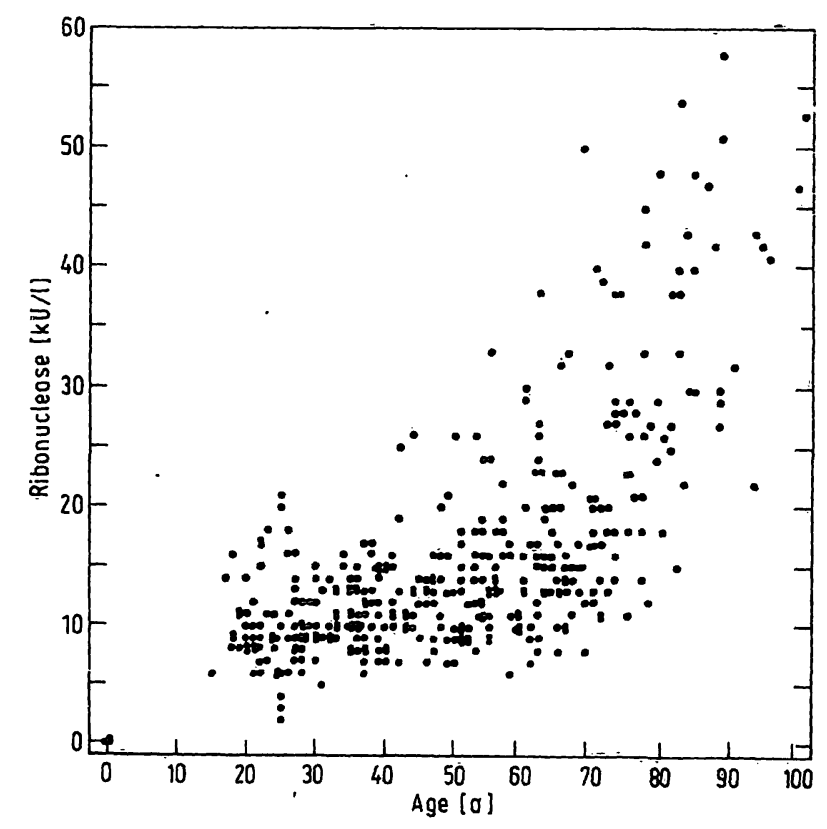

Fig. 1. Correlation between age and ribonuclease activity with Poly $(C)$ as substrate $(n=401 ; r=0.683 ; p<0.001$; $y=0.329 x+0.638$ ). Drawing from a plotter diagramme. Numerous points represent 2-4 identical results.

There is a rapid progression of enzyme activity in subjects older than 60 years, as can also be noticed from the mean values in table 1 .

Ten samples for each decade between 21 and 90 years were also assayed for enzymatic activity with the substrates Poly (U), Poly (A) and Poly (G), and the values 
compared with activity towards Poly (C). As can be seen in table 2 enzyme activity with Poly (C) as substrate shows the typical increase depending on the age of the subject, whereas activity towards all other polyribonucleotides is markedly lower and remains practically unchanged with increasing age.

\section{Discussion}

The great variety of ribonuclease assay techniques and resulting activity definitions makes it difficult to compare results of different authors. This is mainly due to the use of biological substrates, such as RNA preparations from E. coli (mRNA as well as tRNA) and yeast RNA $(1,6$, $4,8,16,17,18)$. The use of synthetic homopolyribonucleotides led to a methodical standardisation $(3,14)$. By this it could be demonstrated that preparations of different organs with ribonuclease activity exert their activity preferentially on different synthetical polyribonucleotides. This was shown for liver, spleen, pancreas, prostate and leucocytes $(4,19-22)$.

Since the investigations of Migliarese (23) elevated activities of ribonuclease have been repeatedly demonstrated in cancer patients $(8,9,10,16,24,25)$. In the current publications analyzing the clinical relevance of ribonuclease and using the above mentioned enzyme assay technique $(10,11,26,27)$, the influence of age on enzyme activity was not evaluated in an appropriate statistical manner and considered when discussing results in patients. Furthermore normal values are mostly based on activities of poorly defined normal controls.

Our results prove evidence that:

a) preferential cleavage of Poly (C) in human serum as described by Reddi (20) is common is both sexes and all age groups;

b) there is a progressive increase of enzyme activity with Poly (C) as substrate with increasing age.

The reason for this behaviour is not clear, two aspects should be taken into consideration:
1. decreased ribonuclease clearance in the older subject 2. decreased ribonuclease inhibition in the older subject. Ribonuclease clearance: activity of serum ribonuclease depends on renal function, mainly on glomerular filtration. It is well known that diseases leading to a deterioration of glomerular filtration consecutively lead to a marked increase of enzyme activity $(2,4,5)$. It may be presumed that in the older subject there is a decrease of glomerular filtration that is not reflected by the method of creatinine clearance. In accordance with this hypothesis we found elevated enzyme activites in patients with diabetes mellitus or angiopathies and "normal" renal function. Another explanation could be an agedependent enzyme-oligomer formation, giving rise to elevated enzyme activity due to diminished glomerular filtration.

Ribonuclease inhibition: since the investigations of Roth (28) there is evidence of a ribonuclease inhibitor in liver preparations. The inhibitory effect on the enzyme of polyadenylates and the reversibility by depolyadenylation (29) and polyamines $(30,31)$ in vitro are unlikely to cause activity changes in vivo. Ribonuclease activity resulting from a balance of activity and inhibition in vivo will be the topic of further investigations.

Enzymatic cleavage of Poly (U), Poly (A) and Poly (G) remains throughout all ages at a very low and identical level. Most probably Poly (C) specific ribonuclease is not involved in the degradation of other polyribonucleotides. This cleavage could be a consequence of the action of unspecific phosphodiesterases.

In conclusion it seems mandatory to consider the age of the patient when elevated ribonuclease activities are interpreted. Only those increases that exceed levels for the respective age should be taken to indicate the possibility of pathologic activities.

\section{Acknowledgements}

We wish to thank Mrs. H. Braun for technical and Ing. W. Dorda for statistical assistance.

Tab. 2. Ribonuclease activity with Poly (C), Poly (U), Poly (A) and Poly (G) as substrates in age decades from 21-30 to 81-90 years.

\begin{tabular}{|c|c|c|c|c|c|c|c|}
\hline \multirow[t]{4}{*}{ Age } & \multicolumn{7}{|l|}{ Substrate } \\
\hline & Poly (C) & Poly (U) & & Poly (A) & & Poly (G) & \\
\hline & \multicolumn{7}{|c|}{ Ribonuclease catalytic activity concentration } \\
\hline & $\begin{array}{l}\bar{x} \pm s \\
(k U / l)\end{array}$ & $\begin{array}{l}\bar{x} \\
(k U / l)\end{array}$ & $\begin{array}{l}\text { Fraction of } \\
\text { substrate } \\
\text { Poly (C) }\end{array}$ & $\begin{array}{l}\bar{x} \\
(k U / 1)\end{array}$ & $\begin{array}{l}\text { Fraction of } \\
\text { substrate } \\
\text { Poly (C) }\end{array}$ & $\begin{array}{l}\bar{x} \\
(\mathrm{k} U / \mathrm{l})\end{array}$ & $\begin{array}{l}\text { Fraction of } \\
\text { substrate } \\
\text { Poly (C) }\end{array}$ \\
\hline $\begin{array}{l}21-30 \\
31-40 \\
41-50 \\
51-60 \\
61-70 \\
71-80 \\
81-90\end{array}$ & $\begin{array}{l}11.21 \pm 3.40 \\
11.20 \pm 3.40 \\
12.00 \pm 3.50 \\
13.20 \pm 3.60 \\
14.00 \pm 3.70 \\
27.00 \pm 5.20 \\
40.60 \pm 6.40\end{array}$ & $\begin{array}{l}1.10 \\
1.06 \\
0.99 \\
1.20 \\
1.20 \\
1.12 \\
1.10\end{array}$ & $\begin{array}{l}0.098 \\
0.094 \\
0.083 \\
0.091 \\
0.086 \\
0.041 \\
0.027\end{array}$ & $\begin{array}{l}0.43 \\
0.36 \\
0.32 \\
0.28 \\
0.49 \\
0.27 \\
0.24\end{array}$ & $\begin{array}{l}0.038 \\
0.032 \\
0.027 \\
0.021 \\
0.035 \\
0.010 \\
0.006\end{array}$ & $\begin{array}{l}0.62 \\
0.55 \\
0.60 \\
0.60 \\
0.63 \\
0.60 \\
0.61\end{array}$ & $\begin{array}{l}0.055 \\
0.049 \\
0.050 \\
0.045 \\
0.045 \\
0.002 \\
0.015\end{array}$ \\
\hline
\end{tabular}




\section{References}

1. Bardon, A., Sierokowska, H. \& Shugar, D. (1976), Clin. Chim. Acta 76, 231-243.

2. Ward, D. \& Lea, D. J. (1974), New Engl. J. Med. 281, 208.

3. Fink, Adams, W. S. \& Skoong, W. A. (1971), Am. J. Med. 50, 450-457.

4. Connoly, J. H., Herriot, R. M. \& Gupta, S. (1962), Brit. J. Exp. Pathol. 43, 402-408.

5. Humphery, R. L., Karpetsky, T. P., Newelt, E. A. \& Levy, C. C. (1977), Cancer Res. 37, 2015-2022.

6. Biswas, S. \& Hindocha, P. (1974), Clin. Chim. Acta 51, 285-289.

7. Sigulem, D. M., Brasel, J. A., Velasco, E. G., Rosso, P. \& Winick, M. (1973), Am. J. Clin. Nutr. 26, 793-797.

8. Chretien, P. B., Matthews, W. \& Twowey, P. L. (1973), Cancer 31, 175-179.

9. Sheid, B., Lut, I., Pedrinal, L. \& Nelsom, J. H. (1977), Cancer 39, 2204-2208.

10. Reddi, K. K. \& Holland, J. F. (1976), Proc. Natl. Acad. Sci. USA 73, 2308-2310.

11. Peterson, L. M. (1979), Proc. Natl. Acad. Sci. USA 76, 3630-2634.

12. Singeisen, M., Gyr, K., Viollier, M., Gschwinda, H., Stadler, G. \& Truog, P. (1978), in: Kongreßband der 33. Tagung der Deutschen Gesellschaft fur Verdauung und Stoffwechselkrankheiten 1978, Abstrakt 68. Demeter Verlag, Graefelfing.

13. Deutsch, E. \& Geyer, G. (1975), in: Laboratoriumsdiagnostik, Verlag Brüder Hartmann, Berlin, pp. 181-210.

14. Zimmerman, S. B. \& Sandeen, G. (1965), Anal. Biochem. 10, 444-449.

15. Weber, E. (1967), in: Grundriß der biologischen Statistik, Gustav Fischer Verlag, Stuttgart, pp. 385-395.
16. Kottel, R. H., Hoch, S. O., Parsons, R. G. \& Hoch, J. A (1978), Brit. J. Cancer 38, 280-286.

17. Shenkin, A., Citrin, D. L. \& Rowan, R. M. (1976), Clin. Chim. Acta 72, 223-231.

18. Beard, J. R. \& Razzell, E. E. (1864), J. Biol. Chem. 239, 4186-4193.

19. Frank, J. J. \& Levy, C. C. (1976), J. Biol. Chem. 251, 5745-5751.

20. Reddi, K. K. (1975), Biochem. Biophys. Res. Commun. 67, 110-118.

21. Kuciel, R. \& Ostrowsky, W. (1975), Biochim. Biophys. Acta 402, 253-256.

22. Reddi, K. K. (1976), Biochem. Biophys. Res. Commun. 68 , 1119-1125.

23. Migliarese, J. F. (1958), Proc. Am. Ass. Cancer Res. $2,327$.

24. Levy, A. L. \& Rottino, A. (1959), Proc. Am. Ass. Cancer Res. 3, 36-37.

25. Zytko, J. \& Cantero, A. (1962), Can. Mëd. Ass. J. 86, 482485.

26. Fitzgerald, P. J., Fortner, J. F., Waston, R. C., Schwartz, M. K., Sherlock, P., Benua, R. S. \& Cubilla, A. L. (1978), Cancer 41, 868-879.

27. Warshaw, A. L. \& Lee, K. H. (1979), Surgery 86, 227-334.

28. Roth, J. S. (1967), Meth. Cancer Res. 3, 153-242.

29. Hieter, P. A., Legendre, S. M. \& Levy, C. C. (1976), J. Biol. Chem. 251, 3287-3293.

30. Schmuckler, M., Jewett, P. B. \& Levy, C. C. (1975), J. Biol. Chem. 250, 2206-2212.

31. Levy, C. C., Hieter, P. A. \& Legendre, S. M. (1974), J. Biol. Chem. 249, 6762-6794.

Dr. Mario Francesconi Erste Medizinische Universitätsklinik Lazarettgasse 14 A-1090 Wien 